\title{
PERUVIAN SPANISH SPEAKERS' CULTURAL PREFERENCES IN EXPRESSING GRATITUDE
}

\author{
Carmen García
}

\begin{abstract}
Using Spencer-Oatey's (2005) rapport-management model to analyze data collected in open role-play interactions in Lima, Perú, this paper expands research on the preferred communicative patterns of Peruvian Spanish speakers when expressing gratitude in a situation exhibiting high social distance (+SD) and no power (-P) difference between interlocutors, and where the benefit received from the interlocutor is considerable. It is argued that although the development of interpersonal communication in social interactions reflects the relationship of each speaker with his/her interlocutor and his/her "own values and personal standards" (Furukawa 2000), it also reflects their cultural preferences to manage interpersonal relationships (Spencer-Oatey 2005).

Results show that participants exhibited what apparently is prescribed behavior in this sociocultural context in the realization of their interactional goals: The creation and enhancement of the relationship using communicative strategies respecting the association and equity principles and enhancing the interlocutor's identity face. Despite the fact that disrespect to the interlocutor and violations to her autonomy were voiced, it is asserted here, that given this specific context, this might be expected and permitted behavior.
\end{abstract}

Key words: Gratitude; Peruvian; Spanish; Face; Interpersonal relationships.

\section{Introduction}

According to Haverkate (1993: 160)

Giving thanks is a speech act which serves specifically to redress the balance in the cost-benefit relation between speaker and hearer, which means that the thanking formulas compensate symbolically for the cost invested by the hearer for the benefit of the speaker... not to redress the cost-benefit balance by not thanking the other... is considered as a form of impolite behavior.

Whilst giving thanks can be a voluntary speech act initiated by the speaker responding to an interlocutor's (verbal) actions, it is also true that the contexts or situations where they are issued, their form, frequency, effusiveness or restraint may vary among different cultural groups and the situation they are in.

Giving thanks can occur in a simple speech act (e.g. ;Gracias! 'Thank you') or in combination with other speech acts forming a speech act set (Cohen \& Olshtain 
1981) (e.g. thanking + expressing desire to compensate: ¡Gracias! ¿hay algo que pueda hacer por ti? 'Thank you! is there anything I can do for you?'; praising the interlocutor + thanking: Es bien bravo encontrar una persona así, le agradezco muchísimo 'It is very difficult to find a person like this, I'm very grateful'; thanking + revealing personal feelings: Gracias. Estaba muy desesperado 'Thank you. I was quite desperate'; complimenting + expressing surprise iEs precioso! ;Me has sorprendido! 'It is beautiful! You have surprised me!'). It is argued here that whichever form it takes, when expressing gratitude, speakers will respect their own norms of interaction and threaten/maintain/enhance both their own and the interlocutor's respectability face wants, i.e. their "claim for [respectability and deference] from others, by virtue of the relative position [they] occup[y] in [their] social networks and the degree to which [they are] judged to have functioned adequately in that position..." (Ho, cited by SpencerOatey (2005: 102-103), and their own and the interlocutor's identity face, i.e. "the positive self-values [that people] associate with their various self-aspects" (SpencerOatey 2005: 104).

Although thanking has been extensively studied in English (Aijmer 1996; Aston 1995; Colston 2002; Dumitrescu 2005; Eisenstein \& Bodman 1986, 1993) and Japanese (Nakata 1989; Kim 1994; Kimura 1994; Ogawa 1995; Ide 1998; Kumatoridani 1999; Moriyama 1999; Kotani 2002; Ohashi 2008; among others), it has received little attention in Spanish (Hickey 2005; de Pablos Ortega 2006, 2010; Dumitrescu 2005).

Nevertheless, interest in how different speech acts are performed by different Spanish-speaking groups have resulted in valuable research. Hispanists have studied the performance of assertives (Cordella 1996, 2007; Cordella \& Forbes 1998; Edstrom 2004; Forbes \& Cordella 1999; García 1996, 2004a, 2004b, 2009a, 2009d; directives (Delgado 1995; Fant 2006; García 1993, 2007b, 2007c, 2008, 2011; Márquez Reiter 2002; Ruzickova 2007); commissives (Félix Brasdefer 2006; García 1992, 1999, 2007); and expressives (Achugar 2002; Alba-Juez 2000; Bolívar 2001; Cordella 1990; Cordella, Large and Pardo 1995; De los Heros 1998, 2001; de Pablos Ortega 2006, 2010; Dumitrescu 2004, 2005; García 2009b, 2009c, 2012; Gómez Molina 2002; Grindsted 1997; Hernández-Herrero 1999; Hickey 2005; Lorenzo-Dus 2001; MárquezReiter 2000; Ruzickova 1998; Valdés \& Pino 1981; Wagner 1999; Yañez 1990). Nonetheless, much work has yet to be done. This paper contributes to this body of research by analyzing how one group of Spanish speakers, namely Peruvian Spanish speakers, express gratitude.

Working with Spencer-Oatey's (2005) rapport-management model and data collected in open role-play interactions, we aim to study the preferred communicative patterns of Peruvian Spanish speakers by examining their expression of gratitude, in a situation exhibiting social distance but no power differential between interlocutors. We will first present the theoretical framework used to analyze the behaviors observed; then, we will examine different studies on the expression of gratitude by Spanish speakers to provide a background to compare/contrast Peruvian Spanish speakers' performance. Subsequently, we will present an overview of studies of Peruvian Spanish speakers' performance of different speech acts to see the similarities and/or differences between their performance in thanking and other speech acts and see how thanking fits into their overall rules of interaction. These sections will be followed by a discussion of how the data was collected and analyzed; finally, a discussion of findings will ensue. 
The data are then used to test the following null hypotheses: ${ }^{1}$ When expressing gratitude Peruvian males and females do not differ in their preference for

1. respecting or threatening the equity principle (i.e. people's right to be treated fairly and not imposed upon) and/or the association principle (i.e. people's right to associate with others);

2. respecting or threatening their own and/or their interlocutor face;

3. pursuing relational or transactional wants.

\section{Theoretical framework}

Our analysis uses Spencer-Oatey's $(2000,2005)$ rapport management approach which offers a much wider perspective than Brown and Levinson's politeness framework (1987) to study interpersonal relations by going beyond linguistic strategies as responses to face threatening acts to study how social relationships are constructed, maintained or threatened through interaction (2000: 12). Along these lines, SpencerOatey asserts that the success or lack of success in human interaction depends on people's behavioral expectations, face sensitivities and interactional wants. Thus, the rapport-management approach establishes "a greater balance between self and other" (Spencer Oatey 2008: 12).

Behavioral expectations are based on what people judge to be socially appropriate - i.e. what they believe is prescribed, permitted or proscribed behavior (97) - and this assessment is based on contextually-based conventions, norms and protocols which vary according to the communicative activity and setting and the type of relationship subjects have (99). Conventions, however, exist across a range of domains: The illocutionary domain, which deals with the performance of different speech acts; the discourse domain concerned with the "content and structure of an interchange including topic choice, and the organization and sequencing of information"; the participation domain which considers "the procedural aspects of an interchange", such as turn-taking, overlaps, pauses, listener's responses; the stylistic domain which considers choice of tone, address forms, honorifics, for example; the nonverbal domain which considers aspects as gestures, eye contact, proxemics (99). For the purpose of this study, given the space constraints, we will concentrate on the illocutionary and discourse domains.

Behavioral expectations, according to Spencer-Oatey, also result from contextually-dependent interactional principles: The equity principle, i.e. people's right to be treated fairly and not imposed upon; and, the association principle, i.e. people's

1 These hypotheses are tested using proportion and difference of proportions test which establish two different levels of validity, .05 or $95 \%$ and .01 or $99 \%$. Kachigan (1986: 184-185) states "[t]ypically, we set $\alpha=.05$ or $\alpha=.01$, so that if the hypothesis $H_{0}$ is in fact true, we will erroneously reject it only 1 time in 20 , or 1 time in 100 , respectively...the value of $z=1.96$ [is] needed to discredit the null hypothesis at the $\alpha=.05$ level of significance... For a significance level $\alpha=.01$, a value of $\mathrm{z}$ greater than 2.58 is needed..." (165). 
right to associate with others. The equity principle, in turn, has three components: "Cost-benefit considerations (the principle that people should not be exploited or disadvantaged), fairness-reciprocity (the belief that costs and benefits should be "fair" and kept roughly in balance), and autonomy-control (the belief that people should not be unduly controlled or imposed upon) (100)." The association principle has three components as well: "Involvement (the principle that people should have appropriate amounts and types of "activity" involvement with others), empathy (the belief that people should share appropriate concerns, feelings and interests with others), and respect (the belief that people should show appropriate amounts of respectfulness for others)" (100).

Spencer-Oatey (2005) distinguishes then between respectability face and identity face. Respectability face is "the prestige, honor or 'good name' that a person or social group holds and claims within a broader community" (102) and "reflects attributes such as biographical variables, relational attributes, social status indicators, formal title/position/rank, personal reputation and integrity (103). Identity face, on the other hand, is based on Goffman's (1967: 5) concept of face, which he defined as being "based on the positive social values that [people] associate with their various selfaspects." These may include, in Spencer-Oatey's model, bodily features and control, possessions and belongings, performance/skills, social behavior and verbal behavior (104). Spencer-Oatey also includes people's "claims to social group membership" as part of identity face.

Interactional wants, the third component in Spencer-Oatey's rapport management approach, can be either transactional or relational. While transactional wants are task oriented, relational goals aim at "effective relationship management" (2005: 107). Furthermore, Spencer-Oatey argues that the success of a transactional goal might depend on the management of a relational goal, and thus both goals might be interconnected.

As seen above, Spencer-Oatey's approach allows for a much wider and in-depth analysis of human interaction than other politeness models. Nevertheless, as Placencia \& García (2007: 16) point out

Although Spencer-Oatey's notion of rapport management seems to be the most adequate to account for the phenomena analyzed under the rubric of (im)politeness to date, and although her framework addresses a number of the criticisms that the traditional models have received, the application of her model does not seem problem free. For instance, the subtle distinctions proposed in relation to considerations of face or sociality rights, which seem to be more easily identifiable in critical incident reports, may not be easy to apply to spoken corpora.

Spencer-Oatey (2005: 135) herself points out the need for research to see if the concepts of behavioral expectations, face sensitivities and interactional goals can be used to explain the management of rapport in conversations. Answering this call, we use her model to explain how Peruvians manage rapport in a very sensitive, albeit not critical, situation. 


\section{The study of expressions of gratitude in Spanish}

Using field notes taken over a number of years immediately after witnessing or participating in different events of present-giving, Hickey (2005) studied how Peninsular Spanish speakers thank the interlocutor. His findings showed that giving thanks in Spain is expected in situations in which a person receives a present or a favor, but not in situations when these are received from a person doing his/her job. In addition, Peninsular Spanish speakers did not exclusively use formulaic expressions (e.g. ¡Gracias! 'Thank you!'), but rather a variety of statements which qualified as expressions of gratitude (like appreciation of the object presented (e.g. ;Es hermoso! iMe encanta! 'It's beautiful! I love it!'). His conclusions ratify findings that Peninsular Spanish speakers observe a preference for positive politeness (Brown and Levinson 1987) manifested in their "effusiveness, personal enthusiasm, admiration and praise of others, rather than negative forms like avoiding intrusion or apologizing for any imposition inadvertently caused" (Hickey 2005: 329).

De Pablos Ortega (2006), on the other hand, collected data using role play and two minidialogues. The first minidialogue illustrated the offering of a gift and the response it elicited, while the second one, a compliment and the response it received. These mini-dialogues were followed by a questionnaire to which participants had to react stating the (in)appropriateness of the response.

The purpose of his study was to examine the differences between Peninsular Spanish speakers' and English speakers' performance of thanking in Spanish and using these results to design teaching materials that would help students develop pragmatic competence in Spanish. His results confirmed Hickey's (cf. 2005) in that they showed that Peninsular Spanish speakers' expression of satisfaction and enthusiasm upon receiving a gift, without the use of a formulaic expression of gratitude, was considered appropriate by Peninsular Spanish speakers. In addition, De Pablos Ortega pointed out that the lack of expression of gratitude upon receiving a compliment was not considered appropriate.

In a later study De Pablos-Ortega (2010) studied the attitudes of native English speakers towards the Spanish language and culture in relation to thanking. Given that the focus of this paper is on the expression of gratitude, we will concentrate exclusively on the results reported on this aspect of his research.

The participants in this study included 100 Spanish native speakers between 18 and 35 years of age who answered a questionnaire organized into 12 different scenarios taking into consideration different types of relationship between interlocutors, different types of object/goods/service received and types of action for which thanking takes place. At the end of each scenario, participants provided written feedback related to the appropriateness, considerateness and politeness of the interchange and the participants' assurance of their perception. He concluded that social distance and the type of object/service received determine the use of the speech act of thanking. When receiving a gift of a material nature, but not of a non-material nature, participants found it important not only to thank but to add a remark to avoid threatening their own negative face; on the other hand, commonplace questions such as questions about the interlocutor's health did not require to give thanks but instead call for questions about the interlocutor's health; finally, it participants did not deem necessary to use the 
thanking formulae in response to good wishes, a compliment or when being granted permission (DePablos-Ortega 2010: 159).

Dumitrescu (2006) collected data using a test of social habits, role play, field notes and literary texts incorporating dialogue. Subjects included 120 Intermediate and Advanced students of Spanish, 20 non-native Spanish speakers, 65 bilingual Chicano and 35 native speakers from Mexico, Spain, El Salvador, Nicaragua, Peru, Colombia and Argentina. Again, we will concentrate on reporting results of native speakers' interactions.

Results showed native speakers producing extensive and elaborate expressions of gratitude when receiving gifts, material favors and invitations expressing not just gratitude, but surprise, delight, indebtedness, etc.; however, when thanking friends and family and when responding to small or predictable favors, they were less expressive. In service encounters, speakers from Argentina and Spain verbalized their gratitude to a lower extent. Thus, Dumitrescu's results confirm both Hickey's (2005) and De PablosOrtega's $(2006,2010)$ mentioned above.

Now, a review of findings of different studies on Peruvians' performance of different speech acts will help us contextualize their expressing gratitude within what we know about their preferred norms of interaction.

\section{Previous studies on Peruvian Interactional Style}

To see how Peruvian Spanish speakers from Lima respect their own norms of interaction and protect/maintain/enhance both their own and the interlocutor's identity and respectability face wants when expressing gratitude, we deem it important to first present a short view of their preferred communicative style as shown in studies of their participation in small talk (De los Heros and Montes 2008) and of their realization of different speech acts, namely refusals to invitations (García 1992), requests for a service and response to requests for a service (García 1993), reprimands and responses to reprimands (García 1996), blaming (García 2009a), expressing condolences (García 2009b), congratulating (García 2009c), complimenting (De los Heros 2001), requests in a service encounter (García 2011), and complimenting professional achievement (García 2012).

Results from these studies lead us to infer that Peruvian Spanish-speakers prefer the expression and maintenance of camaraderie over the expression of deference in their interactions, especially when there is small social distance between interlocutors (-SD), low power differential (-P) and low level of imposition (-R) (as in doing small talk in a traditional context, in responding to insistence, accepting a request, complimenting, complimenting professional achievement, expressing condolences, reprimanding, blaming and when responding to a request for a promise). However, when these circumstances change and there is large social distance $(+\mathrm{SD})$, the power differential is high $(+\mathrm{P})$ and the level of imposition is high $(+\mathrm{R})$, they prefer the expression of deference (as in not engaging in small talk in non-familiar contexts, and also when making a request for a service, refusing a request, refusing an invitation, and responding to a reprimand and responding to a request for a promise).

Recast in Spencer-Oatey's terms (2005), these studies lead us to infer that Peruvian male and female behavioral expectations and (dis)respect for the interlocutor's 
(and their own) respectability and identity face vary in different contexts. In interactions where they are in a -Power position (as in the case of responding to a reprimand (García 1996), requesting in an institutional setting (García 2011), or in a symmetrical power position (as in refusing an invitation (García 1992) and requesting (García 1993), or when there is +SD (as in modern hair salons (De los Heros \& Montes 2008)), they respect the equity and association principles and the addressee's identity and respectability face. Moreover, when they perceive no danger of threatening the interlocutor's identity face, but on the contrary, an opportunity of enhancing it (as in responding to insistence (García 1992), accepting a request (García 1993), complimenting professional achievement (García 2012), the emphasis on closeness rises and blooms. This respect of the equity and association principles and of the addressee's identity and respectability face dramatically changes, however, when they hold a $+P$ position (as in reprimanding (García 1996), blaming (García 2009a)). Here the emphasis on autonomy-control prevails and the interlocutor's identity face is threatened. They also show females to prefer the expression of indirect aggression (blaming) vs. males' preference for overt aggression; females' preference for a personal vs. a business frame of participation (reprimanding) as opposed to males.

Our purpose in this study is to enrich the body of empirical research of Peruvian Spanish speakers' preferred communication patterns in a situation exhibiting + SD and $P$ (i.e. there was no familiarity between interlocutors and no difference in power/authority between them in real life and/or in the situation presented to them) and where the reason for expressing gratitude is warranted. For the purpose of this study, following Vanderveken (1990), we categorize giving thanks as a communicative illocutionary act of the expressive type. Haverkate (1993: 190) defines it as follows:

giving thanks is a speech act which serves specifically to redress the balance in the costbenefit relation between speaker and hearer, which means that the thanking formulas compensate symbolically for the cost invested by the hearer for the benefit of the speaker...not to redress the cost-benefit balance by not thanking the other... is considered a form of impolite behavior.

\section{Method}

Data was collected in Lima, Perú in 2009 using subjects participating in an open roleplay scenario. Even when it is important to recognize the limitations of open role-play to study the expression of emotions when there is no real connection between the participants, role-play allows the persons involved to carry out complete interactions and to have maximum control over their conversational interchange (Scarcella 1979: 277). As Kasper also states (2008: 289), it allows "the course and outcome of the interaction [to be] jointly and contingently produced by the participants, on the basis of prompts specifying the initial situational context."

Although discourse could have been collected from subjects participating in naturally occurring social interactions, this would have been extremely difficult here because we are interested in studying a specific type of interaction in the same context; moreover, the sensitive nature of the situation did not lend itself to openly record interactions without running the risk of being interpreted by all involved as risky. As Hill et al. (1986: 353), quoted in Blum-Kulka (1989: 13), point out "the virtue of 
authenticity in naturally occurring speech must be weighed against its reflection of speaker's sociolinguistic adaptations to very specific situations." The validity of open role-plays in pragmatic research is further recognized by Félix-Brasdefer (2003: 253) who states that they "represent an approximation of spoken discourse, as they show high indices of pragmatic features... [and] allow the researcher to control social variables, such as power and distance, sex, level of education..."

Immediately after the open role-play, subjects answered a written questionnaire about their perception of the interaction as a whole, the interlocutor's and their own participation, and the level of politeness they perceived during the interaction. The answers they provided helped the analyst determine if the subjects' participation was socially appropriate within the communicative activity they were involved in, the setting and the type of relationship they had with the interlocutor as described in the situation. A written questionnaire was chosen in lieu of verbal reports because it provides participants with valuable privacy and freedom to offer their candid feedback. (See Appendix A). In addition, similarly to verbal reports, they "increase the credibility of role-play data, as the subjects' social perceptions of the speech act appear to complement the role-play data (Félix-Brasdefer 2003: 253).”

\subsection{Subjects}

Subjects included twenty adults from Lima, Perú, 10 males and 10 females; all were native Spanish speakers. The average age was 32 for males and 33 for females. Although social class and age were not explicitly controlled for, the random sample contained a cross-section of low, middle and upper middle class both in terms of education and occupation. Five males and four females had a university degree and were practicing professionals (university professors, journalists, accountants and librarians); five males and six females were high school graduates (government and private industry employees, computer technicians, tourist guides, housewives and university students). The interlocutor was a 55 year-old female translator from Lima, someone the subjects did not know. All subjects filled out a consent form agreeing to participate in the study, but they were not remunerated.

\subsection{Tasks}

The subjects and interlocutor were first told they would be presented with a given situation and that they were to engage in a regular, spontaneous conversation which would be audio-taped. Subjects were separately and individually given their instructions.

Subjects were told:

Ud. fue al banco a retirar dinero para su viaje al extranjero. Cuando llega a casa se da cuenta que no tiene su billetera con todos sus documentos personales y su dinero. Ud. está desesperado(a). En ese momento suena el timbre de la casa y Ud. ve a un(a) extraño(a) a la puerta. Abre la puerta y reacciona a lo que él/ella le dice.

'You went to the bank to withdraw some money for a trip abroad you were going to make. When you get home you realize you don't have your wallet with all your personal 
documents or your money. You are very upset. At that very minute, the doorbell rings and you see someone you don't know at the door. You open the door and react to what he/she says.'

The interlocutor, on the other hand, was told the following:

Ud. estaba en el banco esta mañana y encontró una billetera en el piso con mucho dinero y papeles personales (identificación personal, brevete, etc.). Ud. decide ir a la casa del/de la dueña de la billetera y regresarla con todo su contenido.

'You were at the bank this morning and found a wallet with a lot of money and personal papers (ID, driving license, etc.) on the floor. You decide to go to the owner's house and return it with all its contents.'

After receiving the instructions, each subject and interlocutor improvised their conversation.

\subsection{Data analysis}

After all role-plays were completed and taped, interactions were transcribed using conventions designed by Jefferson (1986: ix-xvi). (See Appendix B). Interactions were then characterized in terms of the recurrent types of strategies used and how they reflected participants' behavioral expectations, types of face they respected/threatened and their interactional wants. In the classification of strategies we found useful to use some of Blum-Kulka et al's (1989) terminology, namely grounders (reasons/explanations/justifications).

To test the statistical significance in the use of different types of strategies, a proportions test was used. When comparing the strategies used by males and females, a difference of proportion test was used.

\section{Description and analysis}

When expressing gratitude, subjects used a variety of strategies which we infer responded to the behavioral expectations of their cultural group within the context of this situation. They provided information, expressed agreement with the interlocutor, revealed personal feelings, assumed common values, expressed surprise/disbelief, expressed gratitude, praised the interlocutor, gave reasons/explanations/justifications (grounders), expressed desire to compensate, offered to compensate, expressed indebtedness.. To a lesser degree, they also indirectly accused the interlocutor, verified the information they were being provided with and requested information.

The following provides samples of the different strategies used in expressing gratitude. Participants are identified using the following abbreviations: PM or PF where $\mathrm{P}$ stands for Peruvian; $\mathrm{M}$ and $\mathrm{F}$ for male and female respectively. Bold font is used to highlight the strategy being illustrated.

(1) Providing information

Interlocutor Ah eh mire. He encontrado acá una billetera? co:n di $\uparrow$ nero y: sus 
papeles personales.

PM1 Sí justo he ido al banco-fui-estuve en el banco > y se me ha perdido la billetera y no no sabía cómo buscarla y apareció usted con mi billetera $<=$

Interlocutor 'Uh uh look. I have found a wallet? wi:th $\uparrow$ money a:nd your personal papers

PM1 Yes, I have just been to the bank - I went- I was in the bank > and I have lost my wallet and I didn't didn't know how to look for it and you appear with my wallet $<=$ '

(2) Expressing agreement

Interlocutor =pero igualmente te lo traigo porque pienso que es algo muy impor $\uparrow$ tante y que bueno son tus documentos con los cuales pues [los necesitas diariamente no?,

PM7 [Sí bueno eso es lo más valioso no? pucha pero el dinero ya iba a salir de viaje todo.

Interlocutor '= but I bring it to you just the same because I think it is something very im $\uparrow$ portant and that well they are your documents with which well [you need them every day, right?

[Yes well that is the most valuable thing, right? shoot but the money I was going to go on a trip and all.'

(3) Revealing personal feelings

PM6 Sí no, en verdad no sabes lo que-no sabes el susto que me-que me había me $\uparrow$ tido, estaba traumado $=(\mathrm{LF})$

Interlocutor $(\mathrm{LF})$

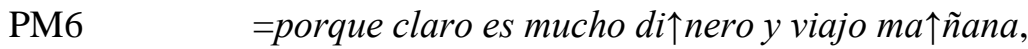
y estaba [muy muy preocupado.

PM6 'Yes no, you really don't know what - you don't know

Interlocutor (LF) how frightened I was, I was [traumatized $=(\mathrm{LF})$

PM6 = = because of course it is a lot of $\uparrow$ money and I am travelling to $\uparrow$ morrow, and I was [very very worried.'

(4) Assuming common values

\begin{tabular}{|c|c|}
\hline PM9 & [Eso-eso hace que uno tenga fe \\
\hline Interlocutor & $\begin{array}{l}\text { [en el prójimo y en el ser humano, } \\
{[\text { Exacto y que usted vuelva a accionar igual no? }} \\
\text { [claro, }\end{array}$ \\
\hline PM9 & [así es, claro que sí, haz por mí::= \\
\hline Interlocutor & Claro hoy por mí [ mañana por ti. Sí. \\
\hline PM9 & $=[$ mañana por ti, así es. \\
\hline PM9 & $\begin{array}{l}\text { ['That -that is what makes one to have trust } \\
\text { [your neighbor and the human being, }\end{array}$ \\
\hline Interlocutor & $\begin{array}{l}\text { [Exactly and that you act the same in turn, right? } \\
\text { [of course, }\end{array}$ \\
\hline M9 & [that's right, of course, do onto me::= \\
\hline $\begin{array}{l}\text { Interlocutol } \\
\text { PM9 }\end{array}$ & $\begin{array}{r}\text { that's right today for me [tomorrow for you. Yes. } \\
=[\text { tomorrow for you, that's right.' }\end{array}$ \\
\hline
\end{tabular}

(5) Expressing surprise/disbelief

Interlocutor [chequea tus co:sas por favor, no he tocado [nada,= 
PF4

[No lo puedo creer!

Interlocutor =simplemente he visto tu dirección $y>$ te la he traído<.

bueno, [prácticamente te he seguido.

Interlocutor ['check your thi:ngs please, I have not touched [anything,=

PF4

[I can't believe it!

Interlocutor $\quad=$ I just saw your address and $>$ I have brought it to you <.

well, [I have practically followed you.'

(6) Expressing gratitude

PF1 [Sí:: yo soy distraidísima. ay! te agradezco mu $\uparrow$ chísimo > y cómo

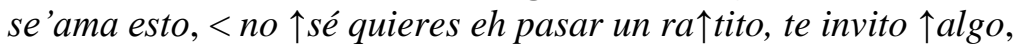
$>$ me siento agradecidísima porque si no imagínate cuando me diera cuenta iba a tener que ir $a-<=$

PF1 ['Ye::s I am very absent-minded oh! I thank you a lot $\uparrow>$ and how do you say, $<$ I don't $\uparrow$ know do you want to come in a $\uparrow$ little while, > I feel very grateful because if not imagine when I realized I was going to have to go to- $<=$,

(7) Praising interlocutor

PF4

Pucha te juro que eres increíble, eres un-un ángel, un ángel guardián que Dios me ha mandado. [Qué bárbara.

PF4 'Shoot I swear to you that you are incredible, you are an- an angel, a guardian angel that God has sent me [how incredible you are.'

(8) Giving reasons/explanations/justifications (grounders)

PM2

la verdad gracias, este:estaba muy desesperado por >por no encontrar mi billetera tenía todas mis cosas< este:: (0.1)

PM2 'the truth thank you, uh: I was very upset for not finding my wallet I had all my things> uh::m (0.1)'

(9) Expressing desire to compensate

=no, >de todas maneras< déjame tu telé:fono:, tu no:mbre no sé, una persona así no puedo yo dejarla ir (0.1) tan fácilmente, algún regali:to, >no sé, < de alguna manera yo tengo [que gratificarte.

PF9 ='no, >for sure $<$ leave me your pho:ne number, your na:me I don't know, I can't let a person like this go (0.1) so easily, some little pre:sent, $>$ I don't know $<$ I have to pay you back some way.'

(10) Offering to compensate

Interlocutor [Ah mira ya ves? si tú eres abogado por ahí de repente=

PF1 Claro cualquier cosita le voy a dar mi tarjeta, =

Interlocutor =algunos documen::tos, claro

PF1 =Sí, toma mi tarjeta?,=

Interlocutor $Y a$,

PF1

Y llámeme no más, búsqueme no más por favor. E:::h no?, de cualquier cosa que yo pueda hacer, ya? $>$ pero< este:: >de ver $\uparrow$ dad,< o para el taxi para sus gastos de::-

Interlocutor PF1 ['Ah see you see? If you are a lawyer maybe perhaps= of course any little thing I will give you my card,= 
Interlocutor $=$ some document::s, of course

PF1

$=$ Yes, here's my card $\mathbf{, =}$

Interlocutor Ok,

PF1 And call me, look for me please. A:::h no?,

Anything I can do, ok?,'

$>$ but <uh:: < rea $\uparrow l l y,<$ or for the taxi for your expenses for::'-

(11) Expressing indebtedness

PM1 Pucha muchas $\uparrow$ gracias, más bien este no sé qué podría: darte porque están todos mis documentos personales todo y te debo:: te debo algo.

PM1 'Shoot many $\uparrow$ thanks, but uh I don't know what I cou:ld give you because all my personal documents are there

and I o::we you something.'

(12) Indirect accusation

Interlocutor =Ah mira, Walter, he encontrado tu billetera: en el banco

y te la estoy trayendo porque están todos tus docume:ntos,

tus pertenencias no?, toma, este:: cheque: a revisa a ver si está todo

completo?,

PM7 Pero me falta el dinero y este:: (0.1) bueno están mis documentos todo pero falta el dinero que he reti $\uparrow$ rado,

Interlocutor Ah sí?=

PM7 $=$ Sí.=

...

Puede ser, pero yo me la he metido en el bolsillo, o puede ser que se me haya caído por lo que había un montón de gente en el banco, igual le-le agradezco por haberla traído y, sí-disculpe si con mi: pregunta la la-la he molestado porque, no creo que una persona que me haya sacado el dinero me-me [traiga la billetera.

Interlocutor $\quad=$ 'Oh see, Walter, I have found your walle:t in the bank

and I am bringing it to you because all your docume:nts are there, your belongings, right?, here, u:h: che:ck check to see if everything is complete?,

PM7 But money is missing and u::h (0.1) well my documents are here everything but the money $I$ with $\uparrow$ drew is missing,

Interlocutor Oh yes?=

PM7 =Yes.=

It can be. but I put it in my pocket, or it could be that it fell out since there was a lot of people in the bank, anyway I thank you -you for bringing it and, yes, excuse me if with my question I have offended you you you because, I don't think a person who has taken out the money would bring me- me the wallet.'

(13) Verifying information

Interlocutor =Sí, ahí la encontré en la puerta. Vi tu dirección, y te la traje.

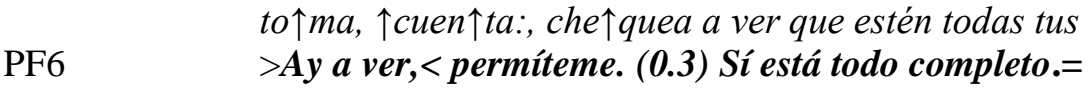

Interlocutor $=$ Sí?

PF6 Sí,= 


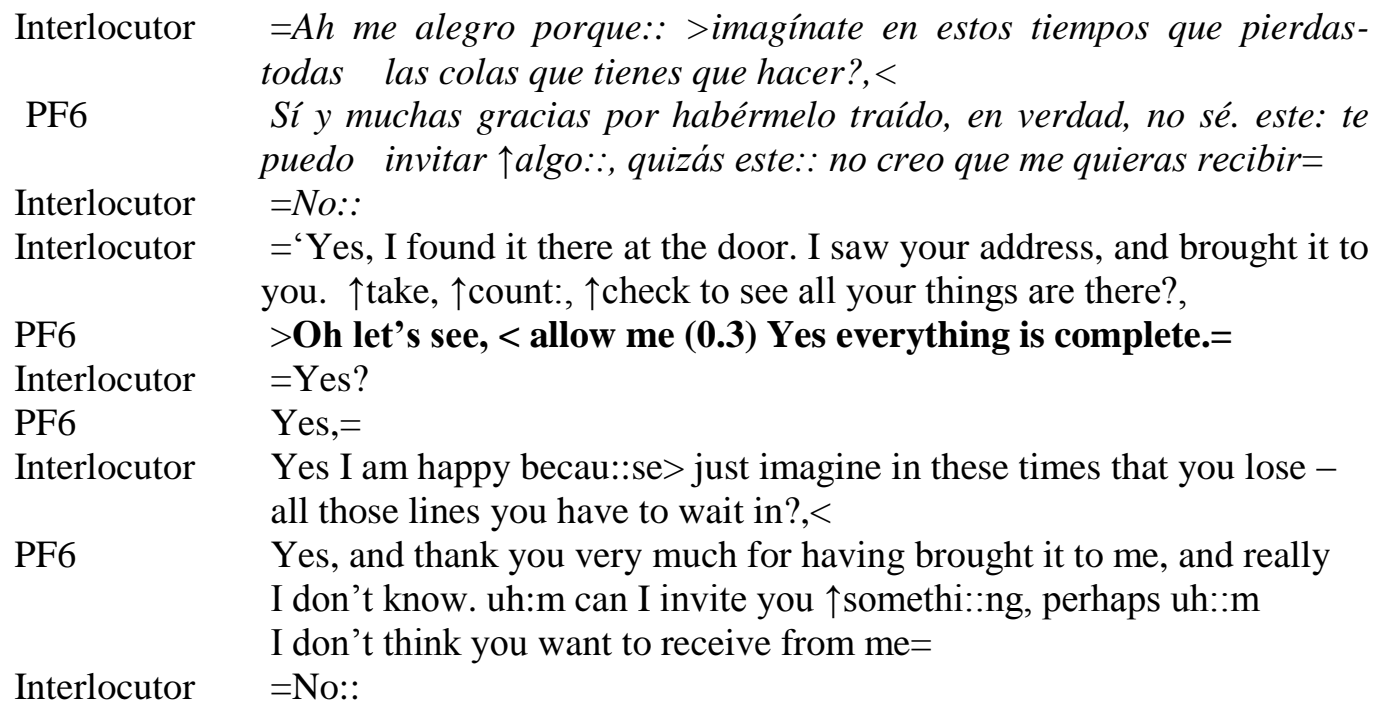

(14) Requesting information.

\begin{tabular}{|c|c|}
\hline PF7 & Pero $: \because(0.2)>$ pero $<y \uparrow$ cómo, cómo los recogió? \\
\hline Interlocutor & $\begin{array}{l}\text { Pues, estábamos ahí en el banco y estaba ahí casi en la puerta } \\
\text {-parece que cuando tú has salido y has estado guarda::ndo } \\
\text { tu: e:h tu D.N.I. o algo para:-o tu tarjeta?, se te ha caído?, } \\
\text { entonces, por eso, chequeé la foto y estabas ahí más } \\
\text { [o menos pude darme cuenta que eras tú o no, }\end{array}$ \\
\hline PF7 & {$[$ Ay, $(0.2)$ sí, y tenía un -un di $\uparrow$ nero, del banco, no?= } \\
\hline $\begin{array}{l}\text { Interlocutor } \\
\text { PF7 }\end{array}$ & $=$ Sí, ahí está, [no he tocado nada, sí, \\
\hline Interlocutor & Puedes chequear, >por eso te digo [si quieres chequea $<$ porque, $=$ \\
\hline $\begin{array}{l}\text { PF7 } \\
\text { Interlocutor }\end{array}$ & $\begin{array}{l}{[\text { No no, }} \\
=\text { de repente se te ha caído algún pape::l, algún otro documento } \\
\text { y puedes }(0.1) \text { regresar y ver no?, y preguntar a los vigilantes. }\end{array}$ \\
\hline PF7 & Mmm, ya, > no no no $<$ si está todo está todo. $=$ \\
\hline $\begin{array}{l}\text { Interlocutor } \\
\text { PF7 }\end{array}$ & $=$ Está todo $?[$ ah:: menos mal $=$ \\
\hline Interlocutor & $=$ me alegro. $=$ \\
\hline PF7 & $=$ Sí, en verdad muchísimas gracias. \\
\hline PF7 & 'Bu:::t $(0.2)>$ but< and $\uparrow$ how, how did you pick them up? \\
\hline Interlocutor & $\begin{array}{l}\text { Well, we were there in the bank and it was there almost at the door } \\
\text {-it looks that when you came out and put everything awa::y } \\
\text { yo:ur u:h your ID or something fo:r: -or your card?, did it fall out?, } \\
\text { then, that's why I checked the picture and you were there more } \\
\text { [or less I could realize it was you or not, }\end{array}$ \\
\hline PF7 & [Oh, $(0.2)$ yes, and I had some - some $\uparrow$ money from the bank, right?= \\
\hline $\begin{array}{l}\text { Interlocutor } \\
\text { PF7 }\end{array}$ & $\begin{array}{c}=\text { Yes, it's there, [I haven't touched anything, yes, } \\
\text { [yeah? Oh ok. }\end{array}$ \\
\hline $\begin{array}{l}\text { Interlocutor } \\
\text { PF7 }\end{array}$ & $\begin{array}{c}\text { You can check,? that's why I tell you [check if you want }<\text { because, }= \\
\text { [no no, }\end{array}$ \\
\hline Interlocutor & $\begin{array}{l}=\text { maybe you have dropped a pape::r, some other document } \\
\text { and you can }(0.1) \text { go back and see no>, and ask the guards. }\end{array}$ \\
\hline & Uhm, yeah $>$ no no no $<$ if everything is here everything is here.= \\
\hline & Is everything there? $>[\mathrm{oh}:$ : it's a good thing $=$ \\
\hline & [yes. \\
\hline
\end{tabular}


Interlocutor =I'm happy.=

PF7

Yes, really many thanks.'

Table 1 presents quantitative information of the strategies used, classified in terms of the behavioral expectations they reflect, specifically their compliance and threat to the association and equity principles.

Table 1

\begin{tabular}{|c|c|c|c|c|c|c|}
\hline \multirow[t]{2}{*}{ Behavioral Expectations } & \multicolumn{2}{|c|}{ Male } & \multicolumn{2}{|c|}{ Female } & \multicolumn{2}{|c|}{ Total } \\
\hline & $\mathrm{n}$ & $\%$ & $\mathrm{n}$ & $\%$ & $\mathrm{n}$ & $\%$ \\
\hline \multicolumn{7}{|l|}{$\begin{array}{l}\text { A. Respecting the Association } \\
\text { Principle }\end{array}$} \\
\hline \multicolumn{7}{|l|}{ 1. Involvement } \\
\hline 1.1 Providing information & 19 & 11 & 9 & 5 & 28 & 8 \\
\hline 1.2 Expressing agreement & 12 & 7 & 10 & 5 & 22 & 6 \\
\hline Subtotal & 31 & 18 & 19 & 10 & 50 & 14 \\
\hline \multicolumn{7}{|l|}{ 2. Empathy } \\
\hline 2.1 Revealing personal feelings & 13 & 8 & 12 & 6 & 25 & 7 \\
\hline 2.2 Assuming common values & 11 & 6 & 12 & 6 & 23 & 6 \\
\hline 2.3 Expressing surprise/disbelief & 5 & 3 & 12 & 6 & 17 & 5 \\
\hline Subtotal & 29 & 17 & 36 & 19 & 65 & 18 \\
\hline \multicolumn{7}{|l|}{ 3. Respect } \\
\hline 3.1 Expressing gratitude & 36 & 21 & 57 & 30 & 93 & 26 \\
\hline 3.2 Praising interlocutor & 11 & 6 & 8 & 4 & 19 & 5 \\
\hline $\begin{array}{cl}\text { 3.3Grounder } & \text { (reasons/explanations/ } \\
& \text { justifications) }\end{array}$ & 19 & 11 & 25 & 14 & 44 & 12 \\
\hline Subtotal & 66 & 39 & 90 & 49 & 156 & 44 \\
\hline Total \# of strategies respecting the AP & 126 & 74 & 145 & 78 & 271 & 76 \\
\hline \multicolumn{7}{|l|}{ B. Respecting the Equity Principle } \\
\hline \multicolumn{7}{|l|}{ 1. Cost-benefit } \\
\hline $\begin{array}{l}\text { 1.1 Expressing desire to } \\
\text { Compensate }\end{array}$ & 19 & 11 & 10 & 5 & 29 & 8 \\
\hline 1.2 Offering to compensate & 6 & 4 & 15 & 8 & 21 & 6 \\
\hline 1.3 Expressing indebtedness & 3 & 2 & 3 & 2 & 6 & 2 \\
\hline Subtotal & 28 & 16 & 28 & 15 & 56 & 16 \\
\hline 2. Fairness-reciprocity & 0 & 0 & 0 & 0 & 0 & 0 \\
\hline 3. Autonomy-control & 0 & 0 & 0 & 0 & 0 & 0 \\
\hline Total \# of strategies respecting the EP & 28 & 16 & 28 & 15 & 56 & 16 \\
\hline \multicolumn{7}{|l|}{$\begin{array}{l}\text { C. Threatening the Association } \\
\text { Principle }\end{array}$} \\
\hline 1. Involvement & 0 & 0 & 0 & 0 & 0 & 0 \\
\hline Subtotal & 0 & 0 & 0 & 0 & 0 & 0 \\
\hline 2. Empathy & 0 & 0 & 0 & 0 & 0 & 0 \\
\hline Subtotal & 0 & 0 & 0 & 0 & 0 & 0 \\
\hline \multicolumn{7}{|l|}{ 3.Respect } \\
\hline 3.1 Indirect accusation & 5 & 3 & 0 & 0 & 5 & 1 \\
\hline 3.2 Verifying information & 3 & 2 & 6 & 3 & 9 & 3 \\
\hline Subtotal & 8 & 5 & 6 & 3 & 14 & 4 \\
\hline Total \# of strategies threatening the AP & 8 & 5 & 6 & 3 & 14 & 4 \\
\hline
\end{tabular}




\begin{tabular}{|l|c|c|c|c|c|c|}
\hline D. Threatening the Equity Principle & & & & & & \\
\hline 1. Cost-benefit & 0 & 0 & 0 & 0 & 0 & 0 \\
\hline Subtotal & 0 & 0 & 0 & 0 & 0 & 0 \\
\hline 2. Fairness-reciprocity & 0 & 0 & 0 & 0 & 0 & 0 \\
\hline Subtotal & 0 & 0 & 0 & 0 & 0 & 0 \\
\hline 3. Autonomy-control & & & & & & \\
\hline 3.1 Requesting information & 8 & 5 & 6 & 3 & 14 & 4 \\
\hline Subtotal & 8 & 5 & 6 & 3 & 14 & 4 \\
\hline Total \# of strategies threatening the EP & 8 & 5 & 6 & 3 & 14 & 4 \\
\hline Total \# of strategies & 170 & & 185 & & 355 & \\
\hline
\end{tabular}

The illustrations and the quantitative information presented above will serve us discern and analyze participants' behavioural expectations, face sensitivities and interactional wants.

\subsection{Behavioral expectations}

Following Spencer-Oatey's (2005) definitions of the different components of the association and equity principles we have classified providing information and expressing agreement as strategies respecting the involvement component of the association since through them the speaker establishes a bond with the interlocutor; revealing personal feelings, assuming common values and expressing surprise have been classified as observing the empathy component since through them the speakers are sharing their feelings and values with the interlocutor; expressing gratitude, praising the interlocutor and grounders have been classified as adhering to the respect component since through them the speaker expresses his/her appreciation for the interlocutor and for what she did. On the other hand, expressing desire to compensate, offering to compensate and expressing indebtedness were classified as strategies respecting the cost-benefit component of the equity principle because they express the speaker's desire to balance the benefit he/she had received with the provider of that benefit.

The following strategies have been classified as threatening the association and equity principles: Indirect accusation and verifying information have been classified as threatening the respect component of the association principle since they express the speaker's distrust for the interlocutor; and, requesting information has been classified as threatening the autonomy-control component of the equity principle since in this case the interlocutor was unduly imposed on by the questioning of how he got the speaker's wallet.

Given the quantitative information presented in table 1 above, the argument that subjects exhibited a rapport-developing orientation, which might be prescribed behavior within the context of this situation, is strongly supported. In fact, participants' responses to the written questionnaire confirmed this. They stated that although initially surprised by the events brought forth by a stranger, they wanted to come to know the individual who had taken the extraordinary trouble of returning their personal property, a behavior that was not a common practice within their sociocultural context.

When observing Peruvian participants' strategies, we first notice a marked preference for the observance of the association and the equity principles (92\% of the 
strategies). Only $8 \%$, threatened them. This difference is highly significant $(\mathrm{z}=13>$ $2.58(\alpha .01))$.

Now, looking at the components of association and equity principles, we observe a preference to comply with the former than with the latter $(76 \%$ vs. $16 \%$ of the strategies); and, within the association principle, an inclination to express respect expressing gratitude, praising the interlocutor and providing reasons/explanations/justifications (grounders). These amounted to $44 \%$ of the strategies vs. $18 \%$ for the expression of empathy and $14 \%$ for the expression of involvement. Only through the expression of desire to compensate, offering to compensate and expressing indebtedness was the cost-benefit component of the equity principle observed. These amounted to $16 \%$ of the strategies used.

Comparing male and female strategies respecting the association principle, we notice that both groups expressed more respect than involvement and empathy (39\% vs. $18 \%$ and $17 \%$ for males, and $49 \%$ vs. $10 \%$ and $19 \%$ for females). Although males balanced their expression of empathy and involvement (17\% and $18 \%$, respectively), and females expressed more empathy than involvement (19\% vs. 10\%), the difference between males and females is not statistically significant. The same can be said about the equity principle. Males and females equally observed the cost-benefit component exclusively (16\% of their strategies).

Now, within this rapport-developing orientation, two violations of the association principle, specifically to the respect component, were observed: Indirect accusation and verifying information. It was only males, though, that made the indirect accusation (just as in blaming (García 2009a)), but females did express their desire to verify the information they were given, namely that all the wallet's contents were there. That is, even when the respect component of the association principle was the most observed, it was also the only one violated, albeit to a very low extent (4\% of the strategies vs. $44 \%$ that respected it). This difference is highly significant ( $\mathrm{z}=17.69>$ $2.58(\alpha .01))$. As far as the equity principle is concerned, only the autonomy-control component was violated by both males and females through the use of requesting information, but this violation amounted to only $4 \%$ of their strategies, that is 4 times less than it was expected.

In sum, the strategies used by participants in this interaction reflected their behavioral expectations where observance of the association principle, specifically the expression of respect towards the interlocutor given her unforeseen behavior within their social context, seems to be prescribed behavior. Although violations to the association and equity principles occurred, they amounted to negligible amounts which would not undermine the relationship that was being created.

We now turn to see how the different strategies used reflect participants' respect and/or threat to their own and/or the interlocutor's face sensitivities.

\subsection{Face sensitivities}

In order to analyze how the strategies used enhance the interlocutor's identity face, those that undermine it, and those that enhance the speaker's identity and respectability face, Table 2 presents quantitative information. 
Table 2

Respecting/Threatening Face sensitivities when Expressing Gratitude

\begin{tabular}{|c|c|c|c|c|c|c|}
\hline & $\mathrm{M}$ & & $\mathrm{F}$ & & Total & \\
\hline A. Enhancing I's Identity face & $\mathrm{n}$ & $\%$ & $\mathrm{n}$ & $\%$ & $\mathrm{n}$ & $\%$ \\
\hline 1. Providing information & 19 & 11 & 9 & 5 & 28 & 8 \\
\hline 2. Expressing agreement & 12 & 7 & 10 & 5 & 22 & 6 \\
\hline 3. Revealing personal feelings & 13 & 8 & 12 & 6 & 25 & 7 \\
\hline 4. Assuming common values & 11 & 6 & 12 & 6 & 23 & 6 \\
\hline 5. Expressing surprise & 5 & 3 & 12 & 6 & 17 & 5 \\
\hline 6. Expressing gratitude & 36 & 21 & 57 & 31 & 93 & 26 \\
\hline 7. Praising the interlocutor & 11 & 6 & 8 & 4 & 19 & 5 \\
\hline $\begin{array}{ll}\text { 8. Grounder } & \text { (reasons/explanations/ } \\
\text { justifications) }\end{array}$ & 19 & 11 & 25 & 14 & 44 & 12 \\
\hline 9. Expressing desire to compensate & 19 & 11 & 10 & 5 & 29 & 8 \\
\hline 10. Offering to compensate & 6 & 4 & 15 & 8 & 21 & 6 \\
\hline 11. Expressing indebtedness & 3 & 2 & 3 & 2 & 6 & 2 \\
\hline $\begin{array}{l}\text { Total \# of strategies enhancing I's } \\
\text { Identity face }\end{array}$ & 154 & 91 & 173 & 94 & 327 & 92 \\
\hline \multicolumn{7}{|l|}{ B. Undermining I's identity face } \\
\hline 1. Indirect accusation & 5 & 3 & 0 & 0 & 5 & 1 \\
\hline 2. Verifying information & 3 & 2 & 6 & 3 & 9 & 3 \\
\hline 3. Requesting information & 8 & 5 & 6 & 3 & 14 & 4 \\
\hline $\begin{array}{l}\text { Total \# of strategies undermining I's } \\
\text { identity face }\end{array}$ & 16 & 9 & 12 & 6 & 28 & 8 \\
\hline Total \# of strategies & 170 & & 185 & & 355 & \\
\hline
\end{tabular}

As seen above, when expressing gratitude, 327 or $92 \%$ of the strategies enhanced the interlocutor's identity face and only 28 or $8 \%$ undermined it. This difference is highly significant $(\mathrm{z}=16.15>2.58(\alpha .01))$. In fact, responses in the written questionnaire confirmed this. The negative effect that the threats to the interlocutor's identity face might have had on the interlocutor, however, was overridden by the overwhelming number of strategies that enhanced her identity face: Providing information, expressing agreement, revealing personal feelings, assuming common values, expressing surprise, expressing gratitude, praising the interlocutor, grounder, expressing desire to compensate, expressing indebtedness. It is argued here, as it has been before (see García 2009a, García 2009b) that the multiple enhancing strategies and the few threatening strategies used had a triple function: In addition to enhancing the interlocutor's identity face, they also enhanced: A. the speakers' identity face because by using them they could claim "a positive social value....by the line [the interlocutor will] assume [they have] taken during [this] particular contact" (Goffman 1967: 5, quoted by Spencer-Oatey 2005: 103); b. their own respectability face since they are protecting how they are "judged to have functioned adequately in [society]..." (Spencer-Oatey); and, finally, c. the interlocutor's respectability face by offering their own positive self-values due to her position or good name within the community.

Comparing male and female participation, we can observe no difference whatsoever in the strategies used to enhance or threaten the interlocutor's identity face ( $91 \%$ vs. $9 \%$ and $94 \%$ vs. $6 \%$, respectively). 


\subsection{Interactional wants}

Participants' interactional wants were mainly relational as is evident in their providing information (thus cooperating with the interlocutor) (sample 1), expression of similar values (samples 2, 5), expression of personal feelings (samples 3,6,7), expression of gratitude and desire to compensate (samples 4, 8, 9). The interlocutor, whose linguistic output was not subject of analysis here other than to offer a context from which to evaluate the subjects' participation, seemed to exhibit relational goals as well. This can be derived from her retrospective written reports confirming that she perceived the interaction as having an unquestionable relational goal. Similar results were found in expressing condolences (García 2009b).

\section{Discussion of findings}

Results from the analysis presented above support findings of studies on Peruvian Spanish speakers from Lima and to a certain extent those of Eisentein \& Bodman (1986, 1993). By providing explanations, expressing agreement, revealing personal feelings, assuming common values, expressing surprise, expressing gratitude, praising the interlocutor, providing grounders, expressing desire to compensate, offering to compensate and expressing indebtedness, participants not only restored the cost-benefit balance by providing elaborate speech act sets in their expression of gratitude, but also showed preference for respecting the association and equity principles as well as the addressee's identity face just as they did when participating in interactions where they were in a-Power position (as in the case of responding to a reprimand (García 1996)), or in a symmetrical power position (as in refusing an invitation (García 1992), and in requesting (García 1993)). By the same token, similarly, to situations where they perceived there was an opportunity to enhance the interlocutor's face (as in responding to insistence (García 1992)), accepting a request (García 1993), making a request for a service in an institutional setting (García 2011) or in small talk (De los Heros \& Montes 2008), where emphasis on closeness thrived, when expressing gratitude, participants tried to develop closeness and solidarity with the interlocutor. Strategies threatening the association and equity principles as well as the interlocutor's identity face, albeit present, were scarce.

Although females were slightly more verbose than males, the differences observed between them in reprimanding (García 1996), blaming (García 2009a) or complimenting (De los Heros 2001), where males were more authoritative than females, or in refusing an invitation (García 1992), where females, but not males, accepted, were not observed here. Both males and females were equally inclined to create the relationship with the interlocutor despite the unexpected behavior she was exhibiting within their cultural context. These similarities between male and female behavior then do not confirm Zimmerman \& West's (1975), Lakoff's (1975), Goodwin's (1980), Holmes' (1995) and Holmes \& Stubbe's (1992) arguments that males hold a more confrontational and aggressive tone than females, at least not in this context.

It is argued here that the strategies used in expressing gratitude reflect interdependent self-construals of self within which "[a] premium is placed on emphasizing collective welfare and showing a sympathetic concern for others" (Markus 
\& Kitayama 1991: 228), or, as Kağitçibaşi (1998) calls it, a culture of 'relatedness' where establishing, maintaining and enhancing in-group relationships is of outmost importance. It is under this perspective that these strategies, and even indirect accusation, verifying information, requesting information are not seen as proscribed behavior, but rather accepted or even expected behavior to develop and possibly enhance the relationship with the interlocutor the same way Bayraktaroğlu \& Sifianou (2001) claim is true for the Turkish and Greek cultures (see also Zeyrek 2001). It is argued here that had the speaker not indirectly accused the interlocutor or questioned her motives and trustworthiness he/she would have appeared as naïve and vulnerable, hence violating his/her own identity face and exposing him/herself to be easily exploited or manipulated by the interlocutor. Moreover, these threatening strategies were followed by apologies, justifications expressions of indebtedness, expressions of gratitude as samples 12,13 and 14 above illustrate.

In perfect synchrony with these behavioral expectations, participants respect the interlocutor's identity and respectability face which, in turn, reflect positively on their own identity and respectability face since "[ $t$ ]he assumption is that while promoting the goals of others, one's own goals will be attended to by the person with whom one is interdependent" (Markus \& Kitayama 1991: 229).

Responses to the written questionnaire administered immediately after the open role-play showed participants, both subjects and interlocutor, stating they had properly expressed gratitude, that the interaction had gone very well, and that there was nothing they would have rather said or not said. Males and females said they first found it unusual that someone would be honest enough to return a lost wallet and ask nothing in return (hay pocos casos en que le puedan devolver las cosas a una persona 'there are few cases where things are returned to a person' (PM9); las personas no suelen hacer eso y menos acá en el Perú 'people don't use to do that, and even less here in Peru' (PF2)). Some of them said they were first apprehensive and felt the need to question her motives and expose her possible next moves, but as the interaction developed they realized there was no danger or threat (rechazó el dinero que le ofreci' she rejected the money I offered her' (PF4); parecía buena gente ('she seemed to be a nice person' (PF3); no hizo preguntas sospechosas, no parecía estar observando la casa 'she didn't make suspicious questions, she did not seem to be observing the house' (PF10); estaba sola, no había nadie más con ella 'she was alone, there was nobody else with her' (PF5), and so reconsidered their initial wariness, expressed gratitude and tried to return the favor.

Comparable with the key values of "freedom and personal autonomy as well as ones emphasizing sociability and solidarity" (Bayraktaroğlu \& Sifianou 2001: 8) that define Greek culture, it is claimed here that in interactions where Peruvians hold a $+\mathrm{P}$ position and when their rights are impinged or perceived to be impinged by a $-\mathrm{P}$ interlocutor (García 1996, 2006, 2009), they prefer to wield control and autonomy; nonetheless, in interactions like the one analyzed here, where there is no power differential or social distance among interlocutors but rather an opportunity to protect or enhance the interlocutor's face (as also seen in García 1992, 1993, 2009 and De los Heros \& Montes 2008), they wholeheartedly rise to the occasion giving emphasis to the establishment of sociability and solidarity by respecting the association and equity principles and protecting the interlocutor's face. 
Comparing these results to those found by De Pablos Ortega $(2006,2010)$ and Dimitrescu (2006), we can see that similarly to Peninsular Spanish speakers when reacting to a major material favor (the return of their wallet full of important personal documents and money), Peruvians deemed it important and necessary to provide elaborate, enthusiastic and effusive responses. However, differently from Hickey's findings (cf. 2005) Peruvian participants did not restrain themselves from using formulaic expressions, apologizing for any imposition caused, expressing indebtedness and promising to repair. That is, adjusting Hickey's words (329), they thanked and were troubled by the giver's trouble in obtaining the gift/favor, getting the best/worst of both worlds 'gift with guilt'.

To see how these results of Peruvian Spanish speakers' rules of interaction agree or differ with those of other Spanish speakers' we would need to compare the realization of this same speech act in a similar setting in different varieties of Spanish. However, given the limited number of studies done, the different data collection methods, the different types of contexts or situations studied and the variety of participants in the different analyses we can only tentatively point out some pragmatic characteristics of the different cultural groups. Márquez Reiter \& Placencia (2005: 190) reporting on Spanish pragmatic variation in the realization of different speech acts and types of face threatened assert that

[t]he degree of positive and/or negative politeness appears to be different in different varieties of Spanish. If we were to place the different studies reported on a politeness continuum, we would find the Argentineans, Spaniards and Venezuelans ... sitting at one end of the spectrum, followed by the Chilean and Uruguayans in the middle and Mexicans, Ecuadorians and Peruvians in a slightly lower position towards the negative end of the continuum.

Results obtained in this study confirm the above assertion. Further studies on Spanish pragmatic variation continue calling attention to differences based on participants' age and gender, and also on at the (sub) regional and situational levels (García \& Placencia 2011).

\section{Conclusions}

Analysis of the data has shown that subjects as a whole exhibited a strong rapport developing orientation using a series of strategies that expressed respect towards the association and the equity principles. It is argued here, and supported by the responses given by the participants in the written questionnaire, that this might be accepted and prescribed behavior within the context of this situation (+ social distance and - power difference between interlocutors), where there was a repair to a significant personal loss. Despite this, or even because of this, we argue, some participants saw fit to violate the association and equity principles (the respect and autonomy-control components, respectively). These violations are seen as permitted or expected behavior given that the interlocutor's behavior (returning a lost wallet) was seen as far-fetched within their cultural context. Overall the strategies used reflect a culture that favors interdependent self-construals or 'relatedness'. 
As far as participants' respect for their own and the interlocutor's face sensitivities, participants significantly enhanced the interlocutor's identity face. It is claimed here that faithful to the interdependent self-construals, the same strategies that were devoted to such an endeavor helped them enhance their own respectability and identity face, and in turn the interlocutor's respectability face by making her the beneficiary of their positive self-values.

Participants' interactional wants were notably relational, both maintaining and enhancing in-group harmony. Nevertheless, when they perceived themselves vulnerable they became confrontational and argumentative, albeit briefly. As soon as they realized they had misread the interlocutor's intentions, they re-established harmony with her.

It is worthwhile noticing, that just as in the case of blaming (2009a) where there was a perfect synchrony between rapport-challenging orientation, disrespect for the interlocutor's identity and respectability face and a pursuit of relational (exerting control) interactional goals, in the case of expressing gratitude, there was also perfect synchrony between the speakers' rapport-developing orientation, respect for the interlocutor's identity and respectability face wants and their pursuit of relational wants.

Gender comparisons showed that males and females had the same preferences in their observation of the association and equity principles and respect for the interlocutor's face.

The interlocutor's responses all throughout the interaction (although not the same with every participant due to the fact that they were all participating in an open role play which allowed for the co-production of the interaction), as well as their and the participants' responses in the written questionnaire, support the argument that the subjects exhibited accepted or prescribed behavior. This is supported by the fact that the interlocutor did not once complain, protest or confront her interlocutor about her rights being trespassed or her face being threatened, even when her integrity was questioned. Consequently, the violations are seen as permitted behavior in this specific situation in a culture that favors personal involvement.

Differently from Japanese speakers (Coulmas 1981), Peruvians' expression of gratitude, at least in the context of this situation, focused not on the trouble they had caused the benefactor, but on the benefits they had received from him/her. However, given the severity of their indebtedness, many attempted to adjust the situation assuming a social debt which they feel compelled to satisfy (recognizing their indebtedness and offering to compensate); and/or, a moral debt which they try to satisfy by integrating the benefactor to their inner group (assuming common values and praising the interlocutor). On the other hand, similarly, to Peninsular Spanish speakers (Hickey 2000), Peruvians take the positive form of expressing gratitude with their effusiveness, enthusiasm and praise for the interlocutor.

Needless to say, these results cannot be generalized to state they show the preferred behavior of all Peruvian Spanish speakers in a similar situation given the limitation of open role-play interactions and that participants were a random sample comprising members of the low, middle and upper classes. Further studies of real-life interactions with speakers belonging to different social classes and different age groups should help support or refute our findings here and provide richer insights into the Peruvian cultural perspective. In addition, since this study is restricted to one expressive speech act and to a very particular communicative situation, studies of the performance 
of different interactions where expression of gratitude is expressed or reacted to by different Spanish-speaking groups need to be pursued.

\section{Appendix A : Written questionnaire}

Después de participar en esta situación conteste, por favor, las siguientes preguntas:

1. ¿Cuál fue su impresión general de cómo se llevó a cabo la interacción?

2. ¿Qué le pareció la reacción de su interlocutor? Circule la(s) respuesta(-s) que mejor refleje(-n) su opinión. fuerte-débil grosera-educada normal-cortante

3. ¿Cómo podría juzgar su participación? Circule la(-s) respuesta(-s) que mejor refleje(-n) su opinión.

fuerte-débil grosera-educada normal-cortante

4. ¿Hay algo que a Ud. le hubiera gustado decir pero que no dijo? ¿Qué fue eso? ¿Por qué no lo dijo?

5. Hay algo específico que su interlocutor dijo que le molestó? ¿Qué fue eso?

6. ¿Tiene algún otro comentario?

'After participating in this situation please answer the following questions:

1. What was your general impression of how the interaction developed?

2. How do you interpret your interlocutor's reaction? Circle the response(s) that best reflect your opinion.
strong-weak
rude-polite
normal-curt

3. How would you judge your participation? Circle the response(s) that best reflect your opinion.
strong-weak
rude-polite
normal-curt

4. Is there anything you would have liked to say, but didn't? What was that? Why didn't you say it?

5. Is there anything special that your interlocutor said that bothered you? What was that?

6. Do you have any other comment?'

\section{Appendix B: Transcription notation}

Transcription markers customarily override punctuation conventions, whence the absence of normal punctuation marks.

The transcription marks used were:

A. Simultaneous utterances:

[[ to link together utterances that start simultaneously.

B. Contiguous utterances:

$=$ placed between utterances with no time gap uttered by different speakers or to link different parts of a speaker's utterance that has been carried over to another line because of an interruption.

C. Intervals:

(0.0) placed to measure pause lengths (measured in tenths of a second) 


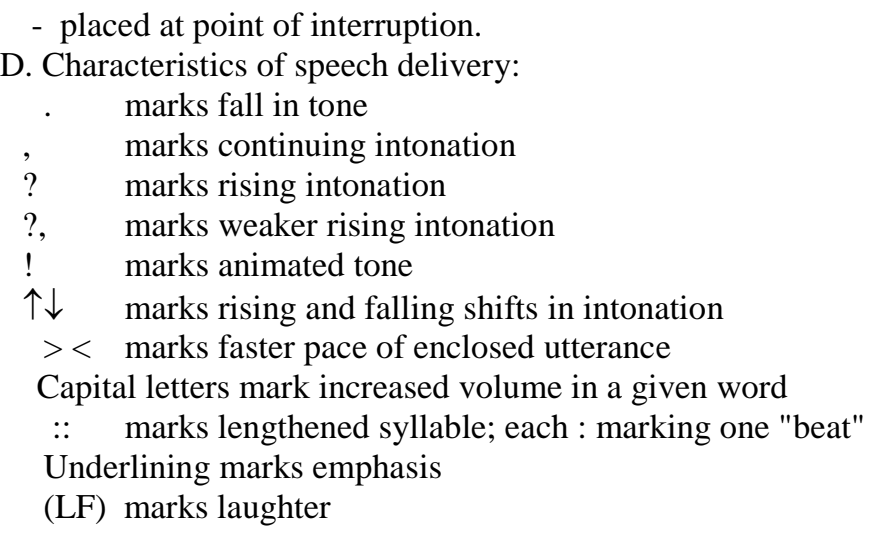

\section{References}

Achugar, Mariana (2002) Piropos: Cambios en la valoración del grado de cortesía de una práctica discursiva. In M.E. Placencia, and D. Bravo (eds.), Actos de Habla y Cortesía y Español. Munich: Lincom Europa, pp. 175-192.

Aijmer, Karin (1996) Conversational Routines in English. Nueva York: Pearson Education.

Alba-Juez, Laura (2000) Some discourse strategies used to convey praise and/or positive feelings in Spanish everyday conversations. In H. Campos, E. Herburger, A. Morales-Front, and T.J. Walsh (eds.), Hispanic Linguistics at the Turn of the Millennium: Papers from the $3^{\text {rd }}$ Hispanic Linguistics Symposium. Massachusetts: Cascadilla Press, pp. 364-380.

Aston, Guy (1995) Say Thank You: Some pragmatic constraints in conversational closings. Applied Linguistics 16: 57-86.

Bateson, Gregory (1972) Steps to an Ecology of Mind. New York: Ballantine Books.

Bayraktaroğlu, Erin, and M. Sifianou (eds.) (2001) Linguistic Politeness across Boundaries. The Case of Greek and Turkish. Amsterdam/Philadelphia: Johns Benjamins Publishing Company.

Blum-Kulka, Shoshana, J. House, and G. Kasper (eds.) (1989) Cross-Cultural Pragmatics: Requests and Apologies. New Jersey: Ablex Publishing Corporation.

Bolívar, Adriana (2001) El insulto como estrategia en el diálogo político venezolano. Oralia 4: 47-73.

Brown, Penelope, and S. Levinson (1987) Politeness. Some Universals in Language Usage. Cambridge: Cambridge University Press.

Cohen, Andrew, and E. Olshtain (1981) Developing a measure of sociocultural competence: The case of apology. Language Learning 31: 113-134.

Colston, Herbert L. (2002) Pragmatic justifications for nonliteral gratitude acknowledgements: Oh sure, any time. Metaphor and Symbol 17: 205-226. 
Cordella, Marisa (1990) Apologizing in Chilean Spanish and Australian English: A cross-cultural perspective. Australian Review of Applied Linguistics 7: 66-92.

Cordella, Marisa (1996) Confrontational style in Spanish arguments: Pragmatics and teaching outlook. Language, Culture and Curriculum 9.2: 148-162.

Cordella, Marisa (2007) "No, no I haven’t been taking it doctor": Noncompliance, face-saving, and facethreatening acts in medical consultations. In M.E. Placencia, and C. García (eds.), Research on Politeness in the Spanish-speaking World. New Jersey: Lawrence Erlbaum, pp. 191-212.

Cordella, Marisa, and K. Forbes (1998) Discourse control and leadership in Spanish conflict talk. Onomazein 3: 45-61.

Cordella, Marisa, H. Large, and V. Pardo (1995) Complimenting behaviour in Australian English and Spanish speech. Multilingua 14.3: 235-252.

Coulmas, Florian (1981) "Poison to your soul": Thanks and apologies contrastively viewed. In F. Coulmas (ed.), Explorations in standardized communication situations and patterned speech. The Hague, the Netherlands: Mouton, pp. 69-91.

Delgado, V.L.C. (1995) Politeness in Spanish: Directives in Colombian and Castilian Spanish and U.S. English. Unpublished Doctoral Dissertation. State University of New York. Dissertation Abstracts International, 55, 2365-A-2366-A.

De los Heros, Susana (1998) El papel del género en la datación y recepción de cumplidos y la cortesía linguística. Cuadernos del Lazarillo: Revista Literaria y Cultural 15: 62-68.

De los Heros, Susana (2001) Discurso, Identidad y Género en el Castellano Peruano. Lima: Pontifica Universidad Católica del Perú.

De los Heros, Susana, and C. Montes (2008) Una primera aproximación al habla de contacto en dos peluquerías limeñas. Oralia 11: 169-190.

De Pablos-Ortega, Carlos (2006) Análisis sociopragmático del habla expresivo de agradecimiento en español. In Antonio Briz, Antonio Hidalgo, Marta Albelda, Josefa Contreras, and Nieves Hernández Flores (eds.), Actas del III Coloquio Internacional del Programa EDICE. Valencia: Universidad de Valencia, pp. 685-691.

De Pablos-Ortega, Carlos (2010) Attitudes of English speakers towards thanking in Spanish. Pragmatics 20.2: 149-170.

Dumitrescu, Dommita (2004) La expresión de buenos deseos hacia nuestro prójimo: ¿un acto de habla cortés automático? In D. Bravo, and A. Briz (eds.), Pragmática sociocultural: estudios sobre el discurso de cortesía en español. Barcelona: Ariel, pp. 265-283.

Dumitrescu, Domnita (2006) Una comparación entre la competencia pragmática de los estudiantes nativos y no nativos del español en California, Estados Unidos. In J. Murillo Medrano (ed.), Actas del Segundo Coloquio del Programa EDICE: Actos de habla y cortesía en distintas variedades del español: Perspectivas teóricas y metodológicas. Programa EDICE. www.edice.org, pp. 375-406.

Edstrom, Anne (2004) Expressions of disagreement by Venezuelans in conversation: Reconsidering the influence of culture. Journal of Pragmatics 36.8: 1499-1518.

Eisenstein, M., and J.W. Bodman (1986) 'I very appreciate': Expressions of gratitude by native and nonnative speakers of American English. Applied Linguistics 7.2: 167-185. doi:10.1093/applin/7.2.167

Eisenstein, Miriam, and J.W. Bodman (1993) Expressing gratitude in American English. In G. Kasper, and S. Blum-Kulka (eds.), Interlanguage pragmatics. NY: Oxford University Press, pp. 64-81. 
Fant, Lars (2006) National cultural norms or activity type conventions? Negotiation talk and informal conversation among Swedes and Spaniards. SYNAPS 19. Bergen: Bergen Business School, pp. 1-22.

Félix-Brasdefer, César (2003) Validity in data collection methods in pragmatic research. In P. Kempchinsky, and C.E. Piñeros (eds.), Theory, Practice and Acquisition. Massachusetts: Cascadilla Press, pp. 239-257.

Félix-Brasdefer, J.C. (2006) Linguistic politeness in Mexico: Refusal strategies among male speakers of Mexican Spanish. Journal of Pragmatics 38.12: 2158-2187.

Forbes, Katie, and M. Cordella (1999) The role of gender in Chilean argumentative discourse. International Review of Applied Linguistics in Language Teaching 37.4: 277-289.

Furukawa, Yukio (2000) "Home" no joukenni kansuru ichikousatsu ['An observation on Conditions for compliments']. Nihongo Nihon Bunka Kenkyuu [Research on the Japanese Language and Culture] 10: $117-130$.

García, Carmen (1992) Refusing an invitation: A case study of Peruvian style. Hispanic Linguistics 5: 207-243.

García, Carmen (1993) Making a request and responding to it: A case study of Peruvian Spanish speakers. Journal of Pragmatics 19: 127-152.

García, Carmen (1996) Reprimanding and responding to a reprimand: A case study of Peruvian Spanish speakers. Journal of Pragmatics 26: 663-697.

García, Carmen (1999) The three stages of Venezuelan invitations and responses. Multilingua 18-4: 391433.

García, Carmen (2004a) Reprendiendo y respondiendo a una reprimenda: Similitudes y diferencias entre peruanos y venezolanos. Spanish in Context 1: 113-147.

García, Carmen (2004b) Coercion and cooperation: A case study of Argentinean reprimands and responses to reprimands. In R. Márquez Reiter, and M.E. Placencia (eds.), Current Trends/Advances in the Pragmatics of Spanish. Ámsterdam: John Benjamins Publishing Company, pp. 231-264.

García, Carmen (2007a) Ché, mirá, vos sabés que no no voy a poder: How Argentineans refuse an invitation. Hispania 90.3: 551-564.

García, Carmen (2007b) Establishing and maintaining solidarity. A case study of Argentinean invitations. In M.E. Placencia, and C. García (eds.), Research on Politeness in the Spanish-Speaking World. Silver Spring, MD: Lawrence Erlbaum Associates Inc., pp. 261-301.

García, Carmen (2007c) Quería pedirte por favor que le hicieras la gauchada: Estrategias de cortesía utilizadas por participantes argentinos en la solicitud de un servicio profesional. In A. Briz, P. Bou, and A. Sopeña (eds.), Pragmática, Discurso y Sociedad. Valencia, Spain: Universidad de Valencia, pp. 153174.

García, Carmen (2008) Different realizations of solidarity politeness: Comparing Venezuelan and Argentinean invitations. In K. Schneider, and A. Barron (eds.), Variational pragmatics. Amsterdam/Philadelphia: John Benjamins Publishing Company, pp. 269-305.

García, Carmen (2009a) The performance of a rapport-challenging act: Blaming. Journal of Politeness Research 5: 217-242. 
García, Carmen (2009b) Cuente conmigo: The expression of sympathy by Peruvian Spanish speakers. Journal of Pragmatics 42: 408-425.

García, Carmen (2009c) ¿Qué::? ¿cómo que te vas a casar? Congratulations and rapport management: A case study of Peruvian Spanish speakers. Pragmatics 19.2: 197-222.

García, Carmen (2009d) Intralingual pragmatic variation in the performance of reprimanding. In K.P. Schneider, and A. Barron (eds.), Intercultural Pragmatics, Special Issue 6-4: 443-472.

García, Carmen (2011) ¿No podría hacer otra cosa para que me den el préstamo? Un estudio sociopragmático de interacciones de servicio entre participantes de Lima. In L. Fant, and A.M. Harvey (eds.), El diálogo oral en el mundo hispanohablante. Estudios Teóricos y Aplicados. Madrid/Frankfurt: Iberoamericana Vervuert, pp. 191-216.

García, Carmen, and M.E. Placencia (2011) Estudios de Variación Pragmática en Español. Buenos Aires: Editorial Dunken.

García, Carmen (2012) Complimenting professional achievement. A case study of Peruvian Spanish speakers. Journal of Politeness Research 8: 223-244.

Gómez Molina, J.R. (2002) El insulto en la interacción comunicativa. Oralia 5: 103-132.

Goffman, Erving (1967) Interaction Ritual. Essays on Face-to-Face Behaviour. New York: Pantheon.

Gómez Molina, J.R. (2002) El insulto en la interacción comunicativa. Oralia 5: 103-132.

Goodwin, Marjorie H. (1980) Directive-response speech sequences in girls' and boys' task activities. In S. McConnell-Ginet, R. Borker, and N. Furman (eds.), Women and Language in Literature and Society. New York: Praeger, pp. 157-173.

Grindsted, Annette (1997) Joking as a strategy in Spanish and Danish negotiations. In F. BargielaChiappini, and S. Harris (eds.), The Languages of Business: An International Perspective. Edinburgh: Edinburgh University Press, pp. 159-182.

Haverkate, Henk (1993) Acerca de los actos de habla expresivos y comisivos en español. In H. Haverkate, K. Hengevel, and G. Mulder (eds.), Aproximaciones Pragmalingüísticas en Español. Diálogos Hispánicos 12. Amsterdam: Rodopi, pp. 149-180.

Hernández-Herrero, A.A. (1999) Analysis and comparison of complimenting behavior in Costa Rican Spanish and American English. Kañina 23: 121-31.

Hickey, Leo (2005) Politeness in Spain: Thanks, but no 'thanks.' In L. Hickey, and M. Stewart (eds.), Politeness in Europe. Clevedon: Multilingua Matters, pp. 317-330.

Hill, Beverly, S. Ide, S. Ikuta, A. Kawasaki, and T. Ogino (1986) Universals of linguistic politeness. Journal of Pragmatics 10: 347-371.

Ho, David Yao-Fai (1976) On the concept of face. American Journal of Sociology 81.4: 867- 884.

Holmes, Janet (1995) Women, Men and Politeness. London: Longman.

Holmes, Jane, and M. Stubbe (1992) Women and men talking: Gender-based patterns of interaction. In S. Olsson (ed.), The gender factor: Women in New Zealand Organizations. Palmerston North: Dunmore Press, pp. 149-163.

Jefferson, Gail (1986) Transcript notation. In J.M. Atkinson, and J. Heritage (eds.), Structures of Social Interaction. Studies in Conversational Analysis. Cambridge: Cambridge University Press, pp. ix-xvi. 
Ide, Risako (1998) Sorry for your kindness: Japanese interactional ritual in public discourse. Journal of Pragmatics 29.5: 509-529. doi:10.1016/S0378-2166(98)80006-4

Kachigan, Sam Kash (1986) Statistical analysis. An interdisciplinary introduction to univariate and multivariate methods. New York: Radius Press.

Kağitçibaşi, Ciğdem (1996) Cross-cultural psychology and development. In J. Pandey, D. Sinha, and D.P.S. Bhawuk, (eds.), Asian Contributions to Cross-cultural Psychology. New York: Sage, pp. 42-49.

Kasper, Gabriele (2008) Data collection in pragmatics research. In H. Spencer-Oatey (ed.), Culturally Speaking. Culture, Communication and Politeness Theory. London: Continuum, pp. 279-303.

Kim, Y. (1994) Nihonjin jyakunensouno 'kansya' to 'wabi'no aisatsuno hyougenno anketo cyousa to sono kousatsu ([A study of the expressions of gratitude and apology in Japanese young generation: In comparison with those in older generation]. Kokugogaku Kenkyuu [The Japanese Language Review] 33: 23-33.

Kimura, Kazumi (1994) The multiple functions of sumimasen. Issues in Applied Linguistics 5.2: 279-302.

Kotani, Mariko (2002) Expressing gratitude and indebtedness: Japanese speakers use of "I'm Sorry" in English conversation. Research on Language and Social Interaction, 35.1: 39-72.

doi:10.1207/S15327973RLSI35-1_2

Kumatoridani, Tetsuo (1999) Alternation and co-occurrence in Japanese thanks. Journal of Pragmatics 31.5: 623-642.

Lakoff, Robin (1975) Language and Woman's Place. New York: Harper and Row.

Lorenzo-Dus, Nuria (2001) Compliment responses among British and Spanish university students: A contrastive study. Journal of Pragmatics 33: 107-127.

Markus, Hazel Rose, and S. Kitayama (1991) Culture and the self: Implications for cognition, emotion, and motivation. Psychological Review 98.2: 224-253.

Márquez Reiter, Rosina (2000) Linguistic Politeness in Britain and Uruguay: A Contrastive Analysis of Requests and Apologies. Amsterdam/Philadelphia: John Benjamins Publishing Company.

Márquez Reiter, Rosina, and M.E. Placencia (2005) Spanish Pragmatics. Basingstoke: Palgrave Macmillan.

Moriyama, T. (1999) Oreito owabi: Kankei syufukuno sisutemu toshite [Gratitude and apologies: A system of repair]. Kokubungaku: Kaishakuto kyouzaino kenkyu [Japanese Literature: Interpretation and Material development] 44.6: 78-82.

Nakata, Tatsuya (1989) Hatsuwa kouitoshiteno chinshato kansha: Nichiei hikaku [Apology and Thanks in Japanese and English]. Nihongo Kyouiku [Journal of Japanese Language Teaching] 68: 191-203.

Ogawa, Haruko (1995) Kansha to wabino teishiki hyougen: Bogowashano shiyou jitttaino cyousa karano bunseki [A study of Japanese formulaic thanks and apologies: A data analysis of the use by Japanese native speakers]. Nihongo Kyouiku [Journal of Japanese Language Teaching] 85: 38-52.

Ohashi, Jun (2008) Linguistic rituals for thanking in Japanese: Balancing obligations. Journal of Pragmatics 40.12: 2150-2174.

Placencia, María Elena, and C. García (eds.) (2007) Research on Politeness in the Spanish-speaking World. New Jersey: Lawrence Erlbaum. 
Ruzickova, Elena (1998) Apologies in Cuban Spanish. In J. Gutiérrez-Rexac, and J. del Valle (eds.), Proceedings of the First Hispanic Linguistics Colloquium. Ohio: Ohio State University, pp. 126-149.

Ruzickova, Elena (2007) Strong and mild requestive hints and positive-face redress in Cuban Spanish. Journal of Pragmatics 39.6: 1170-1202.

Scarcella, Robin (1979) On speaking politely in a second language. In C.A. Yorio, K. Perkins, and J. Schachter (eds.), On Tesol '79. Washington, DC: TESOL, pp. 275-287.

Scollon, Ron, and S.B.K. Scollon (1983) Face in interethnic communication. In J.C. Richards, and R.W. Schmidt (eds.), Language and Communication. New York: Longman, pp. 156-90.

Spencer-Oatey, Helen (2000) Rapport management: A framework for analysis. In H. Spencer-Oatey (ed.), Culturally Speaking. Managing Rapport through Talk across Cultures. London: Continuum, pp. 11-46.

Spencer-Oatey, Helen (2005) (Im)Politeness, face and perceptions of rapport: Unpackaging their bases and interrelationships. Journal of Politeness Research 1: 95-119.

Spencer-Oatey, Helen (2008) Face, (im)politeness and rapport. In H. Spencer-Oatey (ed.), Culturally Speaking. Culture, Communication and Politeness Theory. London: Continuum, pp. 11-47.

Valdés, Guadalupe, and C. Pino (1981) Muy a tus órdenes: Compliment responses among MexicanAmerican bilinguals. Language in Society 10: 73-144.

Vanderveken, Daniel (1990) Meaning and Speech Acts, vol.1. Cambridge: Cambridge University Press.

Wagner, L.C. (1999) Towards a sociopragmatic characterization of apologies in Mexican Spanish. Unpublished doctoral dissertation. Ohio State University.

Yañez, Rosa H. (1990) The complimenting speech act among Chicano women. In J. Bergen (ed.), Spanish in the United States: Sociolinguistic Issues. Washington DC: Georgetown University Press, pp. 79-85.

Zeyrek, Deniz (2001) Politeness in Turkish and its linguistics manifestations. In E. Bayrataktaroğlu, and M. Sifianou (eds.), Linguistic Politeness across Boundaries. The Case of Greek and Turkish. Amsterdam/Philadelphia: John Benjamins Publishing Company, pp. 43-74.

Zimmerman, Don, and C. West (1975) Sex roles, interruptions and silences in conversation. In B. Thorne, and N. Henley (eds.), Language and Sex: Difference and Dominance. Rowley, Massachusetts: Newbury House, pp. 105- 129.

CARMEN GARCÍA (Ph.D. Georgetown University) is Emerita Professor of Spanish Linguistics in the School of International Letters and Cultures (SILC) at Arizona State University. Her research focuses on Spanish pragmatics, Spanish pragmatic variation, intra-cultural communication and Spanish applied linguistics. She co-edited (with María Elena Placencia) "Research on Politeness in the Spanish-speaking World" (2007), "Estudios de Variación Pragmática en español (2011) and a special issue in Oralia (vol. 11, 2008) on Small Talk in Spanish. García is co-founder and co-organizer (with María Elena Placencia) of the ALFAL Research Panel on Spanish pragmatic variation. She is also associate editor of the Studies in Hispanic and Lusophone Linguistics Journal. García has published numerous articles in the area of Spanish pragmatics, Spanish pragmatic variation and foreign language teaching in American and European journals, such as Pragmatics, Journal of Pragmatics, Journal of Politeness Research, Hispania, 
Multilingua, Linguistics and Education. Hispanic Linguistics and Foreign Language Annals. In addition, García has co-authored three Spanish language textbooks, Mosaicos, Interacciones and Mejor Dicho.

Address: Calle Ancha 21, Entreplanta B, 11001 Cadiz, Spain. E-mail: carmen.garcia@asu.edu 